\title{
Evaluation of prenatally diagnosed fetal sacrococcygeal teratomas: A case series of seventeen pregnancies from South-central Turkey
}

Prenatal dönemde tanı konulan sakrokoksigeal teratomlu fetüslerin değerlendirilmesi: Doğu Akdeniz Bölgesinden on yedi gebelik olgu serisi

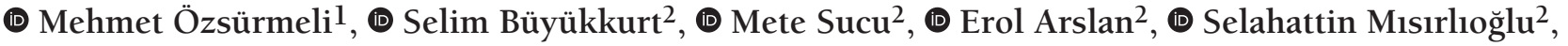 \\ (D) Çiğgem Akçabay², (1) Masum Kayapınar², (1) Süleyman Cansun Demir², (1) İsmail Cüneyt Evrüke² \\ ${ }^{1}$ University of Health Sciences Turkey, Kocaeli Derince Training and Research Hospital, Clinic of Obstetrics and Gynecology, Kocaeli, Turkey \\ ${ }^{2}$ Çukurova University Faculty of Medicine, Department of Obstetrics and Gynecology, Perinatology Unit, Adana, Turkey
}

\begin{abstract}
Objective: To evaluate sacrococcygeal teratoma (SCT) cases according to associated cardiac, extracardiac, and chromosomal anomalies in the prenatal period, and to review their outcomes.

Materials and Methods: Data of pregnancies with a prenatal diagnosis of SCT between 2009 and 2019 were retrospectively reviewed.

Results: One ongoing pregnancy was excluded. There were five medically terminated cases, three due to severe heart failure and the remaining two due to additional congenital defects. Two infants who had heart failure due to hyperdynamic flow died in the neonatal period. Nine infants are well and alive at the time of writing.

Conclusion: When a lesion is detected in the sacrococcygeal region during fetal sonography, the differential diagnosis should be made with an appropriate evaluation with emphasis on a possible diagnosis of fetal SCT. Tumor growth and heart failure should be monitored with serial scans when SCT has been diagnosed prenatally.

Keywords: Prenatal diagnosis, teratoma, sacrococcygeal region
\end{abstract}

Öz

Amaç: Prenatal dönemde tanısı konmuş sakrokoksigeal tümörlü (SKT) fetüslerin kalp, kalp dışı ve kromozom anomaleri ışığında prognozlarının saptanması amaçlanmıştır.

Gereç ve Yöntemler: 2009 ila 2019 tarih aralığında tanısı konmuş SKT’li olguların verileri retrospektif olarak değerlendirildi.

Bulgular: Bir devam eden gebelik çalışmaya dahil edilmedi. Üçü ciddi kalp yetmezliği ve ikisi ek konjenital defektlere bağlı olmak üzere toplam beş olguya tıbbi sonlandırma uygulanmıştı. Hiperdinamik kalp yetmezliği gelişen iki olgunun yenidoğan döneminde öldügü saptandı. Dokuz olgu, makale yazımında sağ ve sağliklıdır.

Sonuç: Fetal sonografi ile sakrokoksigeal bölgede saptanan lezyonların ayırıcı tanısı, fetal SKT tanısı da göz önünde bulundurularak, uygun şekilde ele alınmalıdır. Antenatal SKT tanısı konulduğunda seri muayeneler ile tümörün seyri ve kalp yetmezliği gelişimi takip edilmelidir.

Anahtar Kelimeler: Prenatal tanı, teratom, sakrokoksigeal bölge

PRECIS: In present study, we evaluated prenatally diagnosed cases with sacrococcygeal teratoma and associated anomalies

Address for Correspondence/Yazışma Adresi: Mehmet Özsürmeli, MD,

University of Health Sciences Turkey, Derince Training and Research Hospital, Clinic of Obstetrics and Gynecology, Kocaeli, Turkey

Phone: +90 3223386060 E-mail: ozsurmeli@gmail.com ORCID ID: orcid.org/0000-0002-8853-2815

Received/Geliș Tarihi: 16.01.2020 Accepted/Kabul Tarihi: 19.05.2020

${ }^{\oplus}$ Copyright 2020 by Turkish Society of Obstetrics and Gynecology

Turkish Journal of Obstetrics and Gynecology published by Galenos Publishing House. 


\section{Introduction}

Sacrococcygeal teratomas (SCT) are one of the most common congenital tumors with an incidence of $1 / 35,000$ to 40,000 of live births $s^{(1,2)}$. The teratomas detected in the perinatal period mostly derive from pluripotent primitive stem cells in Hensen's node in the sacrococcygeal region ${ }^{(3,4)}$. Teratomas are classified histologically as mature and immature, and immature elements are composed of primitive neuroglial tissues ${ }^{(5)}$.

Altman et al. ${ }^{(6)}$ described four types of SCTs according to anatomic location. Type 1 tumors are the most common with the majority of the tumor growing outward. In type 2 and type 3 tumors, the tumor has grown into the pelvis and out of the pelvis, respectively, with type 3 tumors growing more extensively into the pelvis. Type 4 tumors are entirely located in the pelvis. According to this classification, the best prognosis is in type 1 tumors $^{(6)}$. Type 1,2 , and 3 tumors can be seen externally because they grow as an exophytic mass (Figure 1). Type 1, 2, and 3 tumors are easier to diagnose in both the prenatal and neonatal periods and have low malignant potential ${ }^{(7)}$. Type 4 tumors are usually diagnosed in the postnatal period and have higher potential for malignancy ${ }^{(8)}$.

SCTs appear as irregular thick-walled masses with cystic and solid components on ultrasound imaging ${ }^{(3,9,10)}$ and should be distinguished from spina bifida. Spina bifida has a significant bone defect and intracranial findings, which tends to be a higher level of the spine. Differential diagnosis includes myelocystocele, lipoma, hamartoma, hemangioma, lymphangioma, and ependymoma in fetal sacrococcygeal region masses ${ }^{(11)}$.

The prenatal course of SCTs is generally unpredictable. However, fetal heart failure due to fetal anemia and high blood flow into the mass can cause fetal hydrops, polyhydramnios, and preterm delivery ${ }^{(12,13)}$. SCTs have become much more detectable in the prenatal period with the increased use of

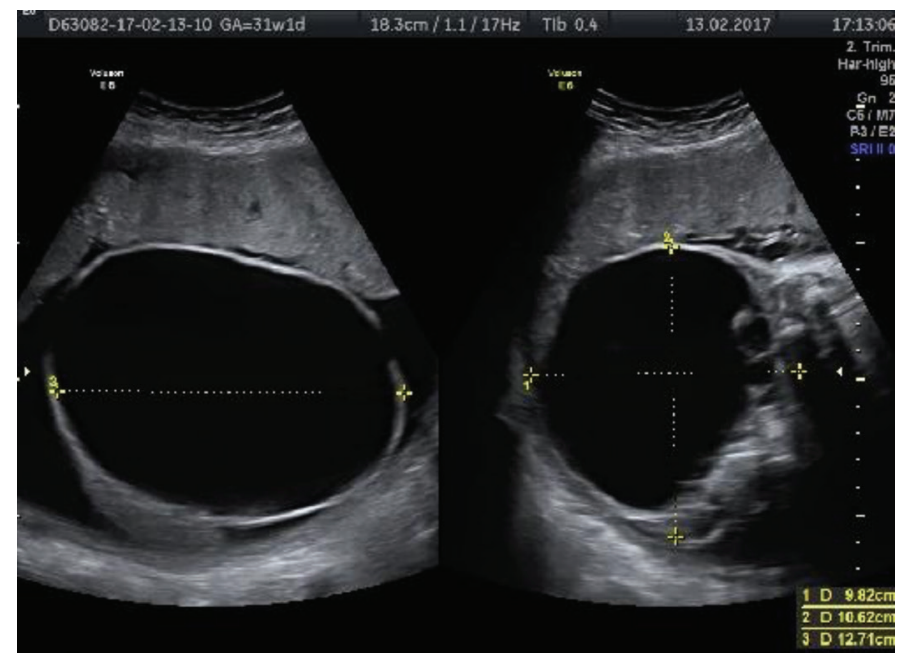

Figure 1. A case of sacrococcygeal teratoma with a cystic component originating from the sacrococcygeal region. The absence of intracranial findings excludes the diagnosis of spina bifida ultrasound scan. Close monitoring and serial ultrasound imaging are supposed to identify some fetuses requiring fetal intervention and preterm birth.

The present case series from a single institution throughout a 10-year-period aimed to assess the characteristics and shortto medium-term follow-up of prenatally diagnosed cases of SCT.

\section{Materials and Methods}

This retrospective study was conducted at Çukurova University Hospital (academic tertiary referral center) Prenatal Ultrasound Unit. All women diagnosed as having fetal SCT from January 2009 to September 2019 were analyzed. Data were collected from the digital patient archiving system. All pregnant women were informed, and written content was obtained. The study was subject to local ethics committee approval (approval no: 14, date: 5.10.2018)

All of the sonography evaluations were performed by one of the seven authors, using a convex volumetric probe (RAB 6-D 2-7 $\mathrm{MHz}$ and RAB2 5L). In general, fetal anatomy scans are performed between 18-22 gestational weeks in the present clinic. The authors also evaluate potential fetal anomalies referred from other centers.

When a heterogeneous mass was seen in the sacrococcygeal region, a differential diagnosis was made. The diagnosis of spina bifida was excluded by demonstrating the continuity of the spinal canal. Color and power Doppler were used to determine blood flow into the mass. Serial ultrasonographic examinations were performed to detect hyperdynamic heart failure, development of fetal hydrops, and tumor growth. Routine fetal karyotyping was not recommended.

Neonatal outcomes were obtained from electronic medical reports, or the family was contacted by phone call. The antenatal findings of all cases with neonatal loss and termination of pregnancy were confirmed with autopsy examinations, except for first trimester terminations.

\section{Statistical Analysis}

The study is the case series. Statistical analysis methods are not used.

\section{Results}

Out of a total of 18,500 fetal anatomy scans throughout the 10-year study period, SCT was detected in 17 pregnancies, revealing a 0.92/1000 incidence rate among high-risk cases in our tertiary setting. The gestational age at diagnosis ranged from 16 to 34 weeks (Table 1). Of the only two fetal karyotypes performed, both were normal. Five of the SCT pregnancies underwent termination of pregnancy. The indication for medical termination was early-onset cardiac failure $(\mathrm{n}=3)$ and additional fetal central nervous defects $(n=2)$. Three fetuses had hydronephrosis due to the urinary obstruction (all with type 3 SCT). Two fetuses 
Table 1. Associated anomalies, clinical features, and outcomes in 16 cases with sacrococcigeal teratoma

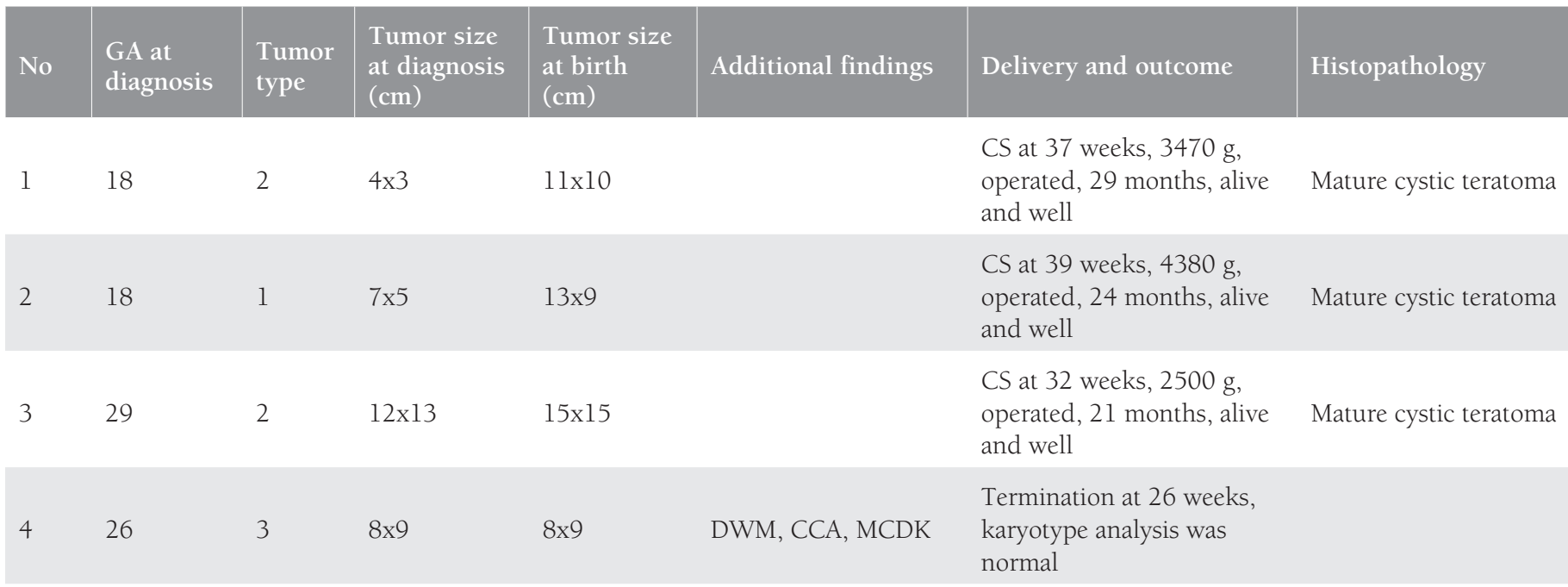

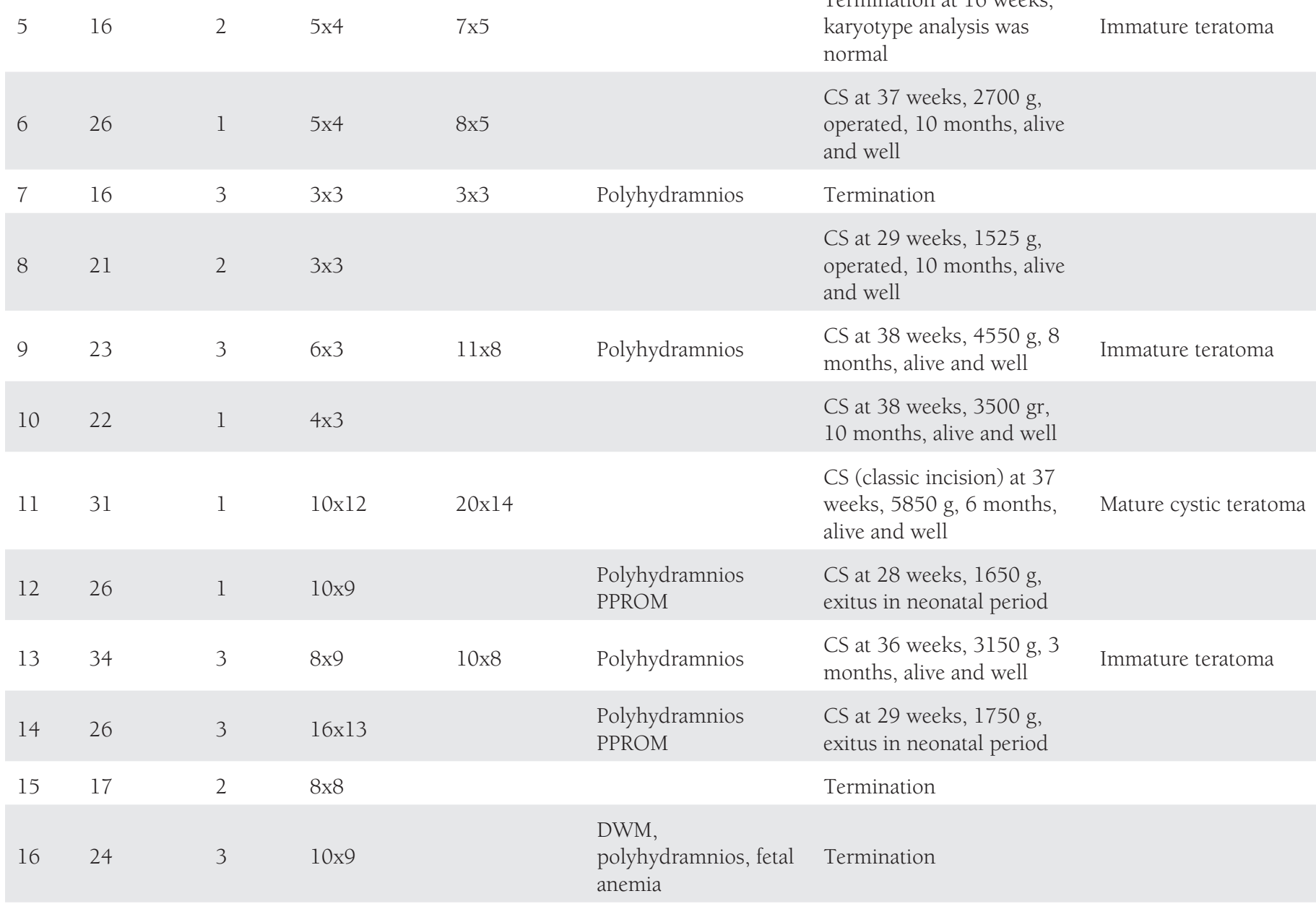

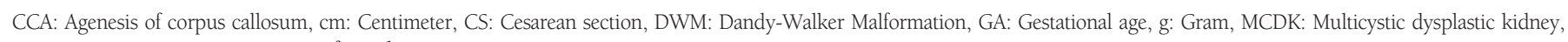
PPROM: Preterm premature rupture of membranes

had fetal cardiomegaly and fetal cardiac failure due to the hyperdynamic flow, and these two fetuses died in the neonatal period. During cesarean section, a classic incision was required in one case, and lower segment transverse incision was used in the others. Almost half of the survivors had type 1 tumors. Nine out of 11 live born infants were alive at the time of writing. The cases are summarized in Scheme 1. 
17 cases with sacrococcigeal teratoma (SCT)

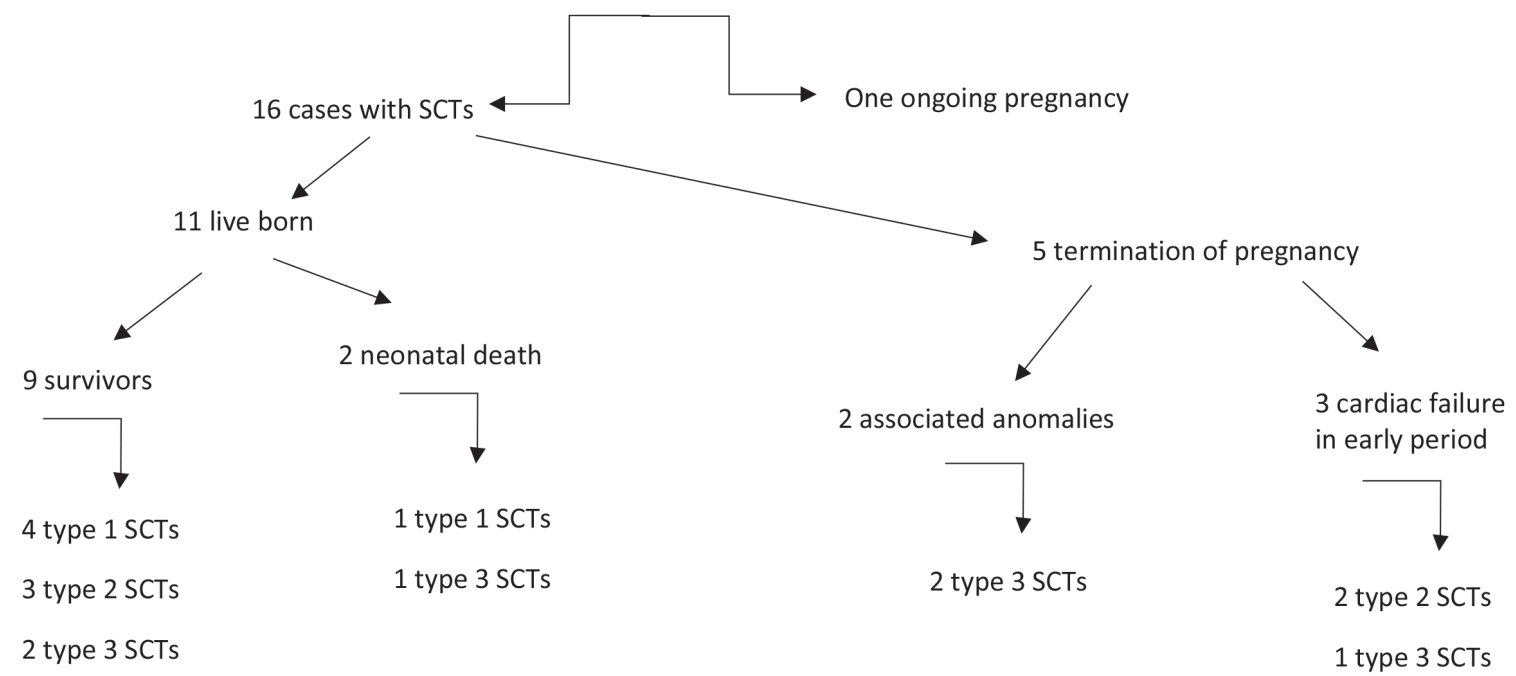

Scheme 1. Seventeen cases with sacrococcygeal teratoma (SCT)

\section{Discussion}

The incidence rate of SCTs in the present design was significantly higher than that reported previously, probably due to referrals to our tertiary setting. Population-based studies are required to delineate the true incidence of SCT in Turkey.

The prognosis of SCTs detected in the prenatal period is worse than those detected in the neonatal period ${ }^{(14,15)}$, explained by the fact that larger-sized tumors are more prone to be detected in fetal life. Tumors detected early in gestation may have a greater growth potential. The prognosis seems to deteriorate when the ratio of tumor volume to estimated fetal weight increases ${ }^{(16,17)}$. In the present study, cases diagnosed at earlier weeks of gestation were associated with adverse prenatal outcomes such as heart failure and termination of pregnancy. Hence, all fetuses with SCT can be monitored for the possible development of heart failure. However, there is no precise information about the most appropriate monitoring protocol because previous data are generally dependent on case series.

SCTs are not usually associated with chromosomal abnormalities. However, cases related to chromosomal abnormalities have also been described ${ }^{(18-21)}$, although this coexistence may be incidental. A previous report described tethered spinal cord associated with $\mathrm{SCT}^{(22)}$. In addition, there was no correlation between the ultrasonographic appearance (cystic or solid components) and the pathology of the tumor. The follow-up of our patients with immature teratoma is ongoing, and no complication has been observed to date.

Fetal magnetic resonance imaging (MRI) may be particularly useful in the differential diagnosis of SCT. Tumor type, solid component content, and tumor volume can also be detected successfully using MRI. However, the authors propose that fetal MRI may be unnecessary except for clinical studies. In the author's opinion, tumor type, blood flow into the tumor, placenta size, and amount of amniotic fluid can be successfully demonstrated with ultrasound.

Tumor morphology is also important in prognosis. In some small case studies, solid tumors have been reported to have a worse prognosis than cystic tumors ${ }^{(15,23,24)}$. There is an increased risk of fetal cardiac insufficiency in solid tumors. These solid tumors may tend to be more vascular and cause more shunting of blood away from the placenta because they grow larger. Solid tumor volumes and derived indices are predictive of mortality and high-output cardiac failure ${ }^{(12,25)}$. We did not measure the tumor solid component volume in our cases, but we confirmed that the prognosis was worse in tumors with solid components. Although there is no consensus on the mode of delivery, the authors recommend cesarean delivery except for early pregnancy termination or very early preterm deliveries. Tumor rupture during delivery can cause bleeding in varying proportions depending on the amount of vascularization of the tumor. It should be kept in mind that larger tumors may require classic uterine incisions. In the presence of a large tumor, an improper incision may cause detrimental tears in the uterus, leading to postpartum hemorrhage.

\section{Study Limitations}

There are some limitations of the present study. First, the study was designed retrospectively. However due to the rarity of the tumor, information on this subject is usually based on retrospective case series. Recommendations such as approach and follow-up frequency in these cases are not based on randomized studies but as an expert opinion. Second, autopsy was declined in most of the cases. When an autopsy is not performed, a definitive pathologic diagnosis of a tumor considered as teratoma with ultrasound cannot be confirmed. Therefore, a false-positive rate cannot be given. Another 
significant limitation is the short follow-up period, especially in immature teratoma cases. Despite these, the most important advantage of our study is the high number of cases of a sporadic rare tumor.

\section{Conclusion}

When a tumor is detected in the sacrococcygeal region, the differential diagnosis including SCT should include an appropriate evaluation. With serial examinations, it is necessary to determine the course of the disease and whether it will lead to heart failure.

\section{Ethics}

Ethics Committee Approval: The study was subject to local ethics committee approval (approval no: 14, date: 5.10.2018).

Informed Consent: All pregnant women were informed, and written content was obtained.

Peer-review: Externally peer-reviewed.

\section{Authorship Contributions}

Surgical and Medical Practices: M.Ö., S.B., M.S., E.A., S.M., C..A., M.K., S.C.D., İ.C.E., Concept: M.Ö., S.B., S.C.D., Design: M.Ö., M.S., E.A., I.C.E., Data Collection or Processing: C..A., M.K., S.M., Analysis or Interpretation: S.C.D., İ.C.E., S.B., Literature Search: S.M., Ç.A., M.S., Writing: M.O., M.K., E.A.

Conflict of Interest: The authors report no conflict of interest. Financial Disclosure: Authors have no financial interests about the research.

\section{References}

1. Swamy R, Embleton N, Hale J. Sacrococcygeal teratoma over two decades: birth prevalence, prenatal diagnosis and clinical outcomes. Prenat Diagn 2008;28:1048-51.

2. Danzer E, Hubbard AM, Hedrick HL, Johnson MP, Wilson RD, Howell LJ, et al. Diagnosis and characterization of fetal sacrococcygeal teratoma with prenatal MRI. AJR 2006;187:W3506.

3. Woodward PJ, Sohaey R, Kennedy A, Koeller KK. From the archives of the AFIP: a comprehensive review of fetal tumors with pathologic correlation. Radiographics 2005; 25:215-42.

4. Mintz B, Cronmiller C, Custer RP. Somatic cell origin of teratocarcinomas. Proc Natl Acad Sci U S A 1978;75:2834-8.

5. Arisoy R, Erdogdu E, Kumru P, Demirci O, Ergin N, Pekin O, et al. Prenatal diagnosis and outcomes of fetal teratomas. J Clin Ultrasound 2016;44:118-25.

6. Altman RP, Randolph JG, Lilly JR. Sacrococcygeal teratoma: American Academy of Pediatrics Surgical Section survey - 1973. J Pediatr Surg 1974:9:389-98.

7. Ayed A, Tonks AM, Lander A, Kilby MD. A review of pregnancies complicated by congenital sacrococcygeal teratoma in the West Midlands region over an 18-year period: population-based, cohort study. Prenat Diagn 2015;35:1037-47.

8. Johnson MP, Mann S. Fetal tumors. In: Rodeck CH and Whittle MJ, editors. Fetal Medicine: Basic Science and Clinical Practice (2nd ed). UK: Churchill Livingstone; 2008. p. 532-5.
9. Kamil D, Tepelmann J, Berg C, Heep A, Axt-Fliedner R, Gembruch $\mathrm{U}$, et al. Spectrum and outcome of prenatally diagnosed fetal tumors. Ultrasound Obstet Gynecol 2008;31:296-302.

10. Heerema-McKenney A, Harrison MR, Bratton B, Farrell J, Zaloudek C. Congenital teratoma: a clinicopathologic study of 22 fetal and neonatal tumors. Am J Surg Pathol 2005;29:29-38.

11. Yu JA, Sohaey R, Kennedy AM, Selden NR. Terminal myelocystocele and sacrococcygeal teratoma: a comparison of fetal ultrasound presentation and perinatal risk. AJNR 2007;28:1058-60.

12. Coleman A, Kline-Fath B, Keswani S, Lim FY. Prenatal solid tumor volume index: novel prenatal predictor of adverse outcome in sacrococcygeal teratoma. J Surg Res 2013;184:330-6.

13. Okada T, Sasaki F, Cho K, Honda S, Naito S, Hirokata G, et al. Management and outcome in prenatally diagnosed sacrococcygeal teratomas. Pediatr Int 2008;50:576-80.

14. Shue E, Bolouri M, Jelin EB, Vu L, Bratton B, Cedars E, et al. Tumor metrics and morphology predict poor prognosis in prenatally diagnosed sacrococcygeal teratoma: a 25-year experience at a single institution. J Pediatr Surg 2013;48:1225-31.

15. Usui N, Kitano Y, Sago H, Kanamori Y, Yoneda A, Nakamura T, et al. Outcomes of prenatally diagnosed sacrococcygeal teratomas: the results of a Japanese nationwide survey. J Pediatr Surg 2012;47:441-7.

16. Rodriguez MA, Cass DL, Lazar DA, Cassady CI, Moise KJ, Johnson A, et al. Tumor volume to fetal weight ration as an early prognostic classification for fetal sacrococcygeal teratoma. J Pediatr Surg 2011;46:1182-5

17. Akinkuotu AC, Coleman A, Shue E, Sheikh F, Hirose S, Lim FY, et al. Predictors of poor prognosis in prenatally diagnosed sacrococcygeal teratoma: A multiinstitutional review. J Pediatr Surg 2015;50:771-4.

18. Wax JR, Benn P, Steinfeld JD, Ingardia CJ. Prenatally diagnosed sacrococcygeal teratoma: a unique expression of trisomy lq. Cancer Genet Cytogenet 2000;117:84-6.

19. Le Caignec C, Winer N, Boceno M, Delnatte C, Podevin G, Liet JM, et al. Prenatal diagnosis of sacrococcygeal teratoma with constitutional partial monosomy 7q/trisomy 2p. Prenat Diagn 2003;23:981-4.

20. Batukan C, Ozgun MT, Basbug M, Caglayan O, Dundar M, Murat N. Sacrococcygeal teratoma in a fetus with prenatally diagnosed partial trisomy 10q and partial monosomy 17p. Prenat Diagn 2007;27:365-8

21. Staboulidou I, Miller K, Göhring G, Hillemanns P, Wüstemann M. Prenatal diagnosis of an epignathus associated with a 49,XXXXY karyotype---a case report. Fetal Diagn Ther 2008;24:313-7.

22. Sivrikoz TS, Has R, Esmer AC, Kalelioglu I, Yuksel A, Taskin OC. Prenatal diagnosis of tethered spinal cord associated with sacrococcygeal teratoma. J Clin Ultrasound 2016;44:506-9.

23. Westerburg B, Feldstein VA, Sandberg PL, Lopoo JB, Harrison MR, Albanese CT. Sonographic prognostic factors in fetuses with sacrococcygeal teratoma. J Pediatr Surg 2000;35:322-6.

24. Lee MY, Won HS, Hyun MK, Lee HY, Shim JY, Lee PR, et al. Perinatal outcome of sacrococcygeal teratoma. Prenat Diagn 2011;31:121721.

25. Sy ED, Filly RA, Cheong ML, Clifton SM, Cortes RA, Ohashi S, et al. Prognostic role of tumor-head volume ratio in fetal sacrococcygeal teratoma. Fetal Diagn Ther 2009;26:75-80. 